\title{
Empowering Young Minds towards Sustainable Development
}

\author{
K. Antony Mary, Elizabeth Margaret, N. V. Kavitha \\ St. Ann's College for Women, Hyderabad, India \\ stann_college@gmail.com,\{margaret_nje,nvkavitha_001\}@yahoo.com
}

\begin{abstract}
The rapid development in science and technology and challenges of globalization are posing additional challenges to education system in the country. Adverse effects of media on mental development and moral values of younger generation are being felt increasingly in all spheres of life. Bringing out latent sublime qualities within the individual and providing for all-round development of personality including physical, mental, intellectual and spiritual aspects should form the goal of education. A student should be trained to balance his Intelligence quotient (IQ), Emotional Quotient (EQ) and Spiritual Quotient (SQ) effectively. The need of the hour is to inculcate human values in Higher Education Institutions (HEIs) to promote societal concern and responsible citizenship. Human Values should be guiding parameters for governance processes at HEIs. HEIs should take suitable measures for disseminating this information in the higher education system to enable sustainable development.

The present paper focuses on the growing demand to lay greater emphasis on quality education, to inculcate, nurture and develop values, particularly among the youth of the country. It is suggested that a Cell for Value Education may be established at every HEI to plan, implement and oversee the requirement to inculcate values in students. It requires sustained efforts to practice, absorb, and assimilate values.
\end{abstract}

\section{Introduction}

Higher Education imparts in depth knowledge and understanding so as to advance the students to new frontiers of knowledge in different walks of life. It develops the students' ability to question and seek truth and makes him/her a competent critique on contemporary issues. It broadens the intellectual powers of the individual within a narrow specialization, but also gives a perspective of the world around.

The report of the UNESCO International commission on Education in the $21^{\text {st }}$ century titled "Learning: The treasure within" (known as Delor's commission) emphasized four pillars of education; learning to know, learning to do, learning to be and learning to live. While Higher Education intends to inculcate all these four pillars in the individuals and in the society, the fourth pillar i.e. learning to live is of different nature, which is of more global in nature. Its omission may result in annihilation of all other educational and developmental efforts. Education for learning to live is primarily about living day by day within a group, a community and a society in which one encounters diverse situation and aspirations.

It involves knowledge and understanding of self and others; appreciation of the diversity of the human race and an awareness of the similarities between, and the interdependence of, all humans; empathy and cooperative social behavior in caring and sharing; respect of other people and their cultures and value systems; capability of encountering others and resolving conflicts through dialogue; and competency in working towards common objectives

\section{A framework for understanding, monitoring and improving education quality}

It is necessary to understand the main elements of quality education systems and how they interact. To this end, we might characterize the central dimensions influencing the core processes of teaching and learning as follows:

- Learner characteristics dimension: How people learn - and how quickly - is strongly influenced by their capacities and experience. Assessments of the quality of education outputs that ignore initial differences among learners are likely to be misleading.

- Contextual dimension: Links between education and society are strong, and each influences the other. Education can help change society by improving and strengthening skills, values, communications, mobility, personal prosperity and freedom. Equally important is whether education takes place in the context of an affluent society or one where poverty is widespread.

- Enabling inputs dimension: Other things being equal, the success of teaching and learning is likely to be strongly influenced by the resources made available to support the process and the direct ways in which these resources are managed.

- Teaching and learning: The teaching and learning process is closely nested within the support system of inputs and other contextual factors. 
Teaching and learning is the key arena for human development and change. It is here that the impact of curricula is felt, that teacher methods work well or not and that learners are motivated to participate and learn how to learn.

- Outcomes dimension: The outcomes of education should be assessed in the context of its agreed objectives. They are most easily expressed in terms of academic achievement, though ways of assessing creative and emotional development as well as changes in values, attitudes and behavior have also been devised.

The Indian Higher Education system is in a constant state of change and flux due to increasing needs of expanding access to Higher Education, impact of technology, increasing private participation and the impact of globalization. Taking cognizance of these issues and development, the core mission of Higher Education is to foster global competencies among students, inculcate value system, promote the use of technology, quest for excellence and contribute to the development of nation.

In a country like India, with cultural pluralities and diversities, it is essential that students imbibe the appropriate values commensurate with social, cultural, economic and environmental realities, at the local, national and universal levels. This paper focuses on the need to lay greater emphasis on empowering the youth for a sustainable development by inculcating, nurturing and developing values.

\section{Empowering young minds - Value Based Education}

There is a strong need to relate the education with the sensible aspect of life where a student can be skilfully made responsible for his/her behaviour or actions. The relevance of life skills is that it provides the ways to be used for better understanding of ourselves and of our surroundings to solve the life's conflicting situations.

As it is said Education begins with the student and not the subjects. Education must be allowed to blossom from within the student, from the heart of the student -everything lies only there. The external ingredients have to be provided as and when needed as props and guides. Thus education can be defined as one which is not limited to acquiring information but has to be tagged with development of moral and ethical values and its end point has always been the formation of a wholesome individual.

Bringing out the latent sublime qualities within the individual and providing for the all-round development of the personality including the physical, mental, intellectual and spiritual aspects should form the goal of education. How to achieve this goal and what inputs are necessary towards this end are subjects of a careful and intense study. To enable the head, heart and hands work harmoniously, a student should be trained to balance his Intellectual Quotient (IQ), Emotional Quotient (EQ) and Spiritual Quotient (SQ) effectively.

Intellectual quotient (IQ) - is an inquiry based learning in which the learner extracts meaning from experience. It is a process that provides opportunities for learners to engage in the practices of life beyond classroom -using tools and methods of scientists, problem solvers or citizens in society -to gain a deeper understanding of themselves and the world around them. This process is situational, personal, action based, social and reflective.

Emotional quotient (EQ) is the capacity to recognize one's own feelings and those of others. It helps to motivate oneself, manage emotions of self and others; contribute to effective performance both in the job and developing satisfying relationship in life. As it is evident from the past, that most of the leaders succeeded because of EQ. Four essential capabilities of Emotions are Self-awareness, Selfmanagement, Social awareness and Social skill.

Spiritual Quotient (SQ) - IQ and EQ are the integral part of Spiritual Quotient (SQ). Spiritual intelligence is not necessarily related to religion. According to Zohar, Spiritual intelligence is about the human need and talent for finding meaning in experience. She says" it is our access to and use of meaning, vision, and value in the way that we think and the decision that we make" SQ cannot be quantified or measured, whereas IQ and EQ may be assessed. The reason being that, the very essence of spiritual intelligence is in seeking a bigger and broader, ever growing perspective. SQ may also be seen as the highest and ever growing need in the mankind.

\section{Value based Education as identified by WHO}

World Health Organisation (WHO) 1993 report mentions that value based life skills comprises of 10 skills (5 pairs) and divides the intelligence behaviour into three types as follows:

Cognitive Domain: It consists creative thinking (the broadened thinking on original or innovative or artistic work etc.) and critical thinking (the deliberation thinking, while analysing any situation problem).

Affective Domain: The value based skills important in this domain are self-awareness (finding and understanding good and bad points of oneself) and empathy (imaginative and spontaneous projection of one's self in to an object or being, leading to sympathetic understanding or vivid experience of events witnessed).

Psychomotor Domain: It emphasize three pairs - 
- interpersonal relationship and communication,

- decision making and problem solving and

- Coping with emotions and coping with stress.

It is the interplay between the skills that produces powerful behavioural outcomes in the individual's personality. Thus value based education can help the youth to overcome the obstacles in life.

\section{Process of empowering students}

First, empowering students is equated with student evaluation. Students are invited to provide their views on the content and organization of the programs of study in which they are involved. These are fed back into the day-to-day management and teaching of the programme and into the longer-term strategic plans.

Second, empower students by giving them more control over their own learning. This ranges from allowing students to select their own curriculum to students entering into a learning contract. The selection of a curriculum usually means, in practice, choosing which teaching programmes they can attend and thus which assessment they undertake.

Third, a student charter empowers students, as like any other 'consumer charter', it sets out expectations and obligations in a transparent way and thus gives students a greater say about the nature and purposes of higher education as a whole. There are various ideas of what such a charter should involve and these reflect various degrees of student empowerment.

Fourth, students are empowered by developing their critical thinking, or metacognition. This requires an approach to teaching and learning that goes beyond the requirements of the students to learn a body of knowledge and be able to apply it analytically. It is about encouraging students to challenge preconceptions, their own, their peers and their teachers. It enables students to easily go beyond the narrow confines of the 'safe' knowledge base of their academic discipline to applying themselves to whatever they encounter in the post education world.

It goes without saying that education is to be linked with socio-economic needs of the society. The purpose of education is not to create human robot or to supply skilled manpower to the global market. Instead, education must become an effective instrument of economic development and social change.
On the social front, the country is marked by cleavages and dissensions. Right kind of education, tuned to the economic and social needs of the society, is the only answer to our socio-economic problems. Education must be able to produce an army of skilled personnel with social sensitivity that will address itself to the problems of the society with a sense of commitment.

\section{Teacher -the agent of change for character building}

Human values are better transmitted than taught. Gurudev Rabindranath Tagore in Shiksha Vidhi said, "In our social system we need teachers who can initiate change in our life and mobilize our mindset and in our education system we need teachers who can empower us to remove obstacles from our life stream.”

In the present socio cultural field teachers have to reinterpret the values as per demands of the changing times. They have to be innovative in attitude, flexible in approach and reflective in mind. Unless they practice what they preach, they will not be able to induct, manage and develop youth towards the state of self actualization i.e. help them to discover their potentialities, talents and capabilities.

Teachers can empower the students' conscience by integrating ethics and moral and spiritual principles into their lives. This changes the attitude, repels negativity and propels them towards divinity. It has been realized that by this there is cohesion between their thoughts, words and actions thereby slowly shaping their lives into enlightened lives, or it can be said towards the state of self actualization i.e. help them to discover their potentialities, talents and capabilities.

The teachers are the source of inspiration and also a model for the development of moral and human values-not only among their students, but in the society. The teachers' task is not merely to impart knowledge, they have also to mould the character of their students and thereby the character of the entire society. Character building includes the development of moral as well as human values.

\section{Life skills for various issues of life}

The values and life skills which the student imbibes as she/he traverses the path of value based education - empower and enable them to successfully confront various life issues as follows: 
Table 1. The values and life skills

\begin{tabular}{|c|c|c|}
\hline S.No. & Issues & Life skills to be used. \\
\hline 1. & HIVIAIDS prevention & $\begin{array}{l}\text { Decision Making (Evaluating future consequences of } \\
\text { present actions), Motivation Skill, Self-disclosure, } \\
\text { Positive Thinking, Critical Thinking, (analyzing peer } \\
\text { group and media) }\end{array}$ \\
\hline 2. & Tobacco use prevention/drinking problem & $\begin{array}{l}\text { Decision making (Resisting peer pressure), Critical } \\
\text { Thinking (identifying social factors that influences the } \\
\text { use of tobacco), Assertiveness skills, Refusal skill, } \\
\text { Positive Thinking, Communication Skill (informing } \\
\text { others), Self awareness. }\end{array}$ \\
\hline 3. & Drug of substance abuse prevention & $\begin{array}{l}\text { Decision making, Assertiveness skills, Positive } \\
\text { thinking, Refusal skills. }\end{array}$ \\
\hline 4. & Peace Education & Negotiation and Conflict management. \\
\hline 5. & $\begin{array}{l}\text { Value Education or personal Development or } \\
\text { Leadership Qualities. }\end{array}$ & $\begin{array}{l}\text { Whole set of life skills can be utilized, special } \\
\text { emphasis on Critical Thinking , Decision Making, } \\
\text { empathy etc. }\end{array}$ \\
\hline 6. & Social Awareness about social evils & Empathy, Inter Personal Relationship, Advocacy skill \\
\hline 7. & Effective Communication & Communication skill \\
\hline 8. & Economic or Political Issues & Critical Thinking, Judgment Thinking \\
\hline 9. & Study Habits & Time management, Self-motivation, Self-development \\
\hline 10. & Stress/Anxiety & $\begin{array}{l}\text { Coping with emotions and stress management skill, } \\
\text { Positive Thinking, Relaxation techniques. }\end{array}$ \\
\hline 11. & Literacy Movement & $\begin{array}{l}\text { Inter Personal Relationship, Communication, } \\
\text { cooperation and Teamwork, Networking, Motivational } \\
\text { Skills. }\end{array}$ \\
\hline 12. & Creativity & Creativity Thinking \\
\hline 13. & Environment Education & Social interaction, social responsibility \\
\hline 14. & Job Perspectives/Professional Development & 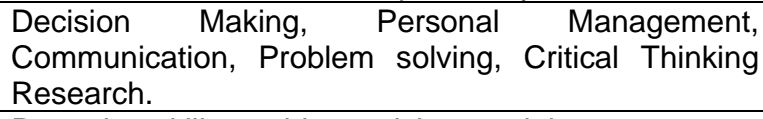 \\
\hline 15. & Child abuse & Parenting skills, problem solving, social support \\
\hline 16. & Sex Education & $\begin{array}{l}\text { Sexual Decision Making, STD/HIV prevention, } \\
\text { Abstinence, Prevention of Sexual Exploitation, } \\
\text { Encouraging Responsible Sex Behaviour, importance } \\
\text { of pregnancy, contraceptive methods. }\end{array}$ \\
\hline 17. & Money Management & Decision Making, Problem Solving. \\
\hline 18. & Health Education & $\begin{array}{l}\text { Decision Making, Refusal skills, identifying personal } \\
\text { preferences among nutritious foods and snacks }\end{array}$ \\
\hline 19. & Family Responsibilities & Self Awareness, Decision Making, Critical Thinking. \\
\hline 20. & Cooperation and team work & $\begin{array}{l}\text { Respecting others, contributions, contributing } \\
\text { positively to the group. }\end{array}$ \\
\hline
\end{tabular}

\section{Policies and procedures in imparting value based Education}

- A Cell for Value Education may be established at every HEIs to plan, implement and oversee this requirement to inculcate values in the students. At the same time, it requires sustained efforts to practice, absorb, and assimilate values.

- It is desirable that in HEIs, human values should permeate and form part of the teaching in all disciplines and subjects.

- The HEIs may work towards evolving a syllabus for a compulsory paper of appropriate credits at the undergraduate level of all disciplines, to stress human values and
- the duties laid down in the constitution and the same may be suitably supported by the methodology and examination/evaluation criteria facilitating a learner-centric approach.

- At the same time, a few institutions having the potential for imparting value-based education may be identified as "Institutions of Excellence" and act as models for all HEIs.

- Efforts should be made by HEIs to impart the teachers, by providing the necessary skills and insights into value education by devising suitable orientation courses and extending support to institutions for imparting such training.

- Human Values should be the guiding parameters for governance processes at higher education 
institutions. HEIs should take suitable measures for disseminating this information in the higher education system.

- Due recognition should be given to the expanding socially relevant role of open education and to explore the methods of communicating and internalizing "Human Values" among the students. Special attention should also be given to develop appropriate study material for this on a priority basis through proper supportive measures.

- It is also recommended that the evaluation criteria of institutions should be transparent to give due weight to the inculcation of human values.

\section{Conclusion}

Efforts should be made to enable the education of the learner towards sustainable development and thus shall be directed towards:

- The development of the learner's personality, talents and mental and physical abilities to their fullest potential

- The development of respect for human rights and fundamental freedoms, and for the principles enshrined in the Charter of the United Nations

- The development of respect for the parents, his or her own cultural identity, language and values, for the national values of the country in which the child is living, the country from which he or she may originate, and for civilizations different from his or her own

- The preparation of the student for responsible life in a free society, in the spirit of understanding, peace, tolerance, equality of sexes, and friendship among all peoples, ethnic, national and religious groups and persons of indigenous origin

- The development of respect for the natural environment.

\section{References}

[1] Anil K Agarwal, "Beyond examination reforms" University news, Volume 44 No: 28, July 10-16, 2006.

[2] Annual Report, 2006-2007, Ministry of Human Resources Department, Government of India.

[3] EFA Global Monitoring Report 2005.

[4] Kurup M. R, "Curriculum Design: A reality check in affiliating universities" University News Volume 44, no: 50 Dec 11-17, 2006.

[5] Meena, "The need for life centered education via life skills paradigm” University News Volume 48, no: 17 April - May 2010.
[6] Patel M.R; Arolkar D B, "Faculty development: “An avenue to Quality enhancement In the Higher Education”, University News Volume 44 No: 25 June 19-25, 2006.

[7] Sridhar M K, Ramesh N; "Academia-Industry Intervention: Towards A conceptual Perceptive.” University News, Volume 45, No: 19, May 7-13, 2007.

[8] Sungoh S M, "Effective University Teaching" University News Volume 44, No: 50 Dec 11-17, 2006.

[9] "Students Perception of Quality in Higher Education: A Case study.” University News 44 No: 46, Nov 13-19, 2006.

[10] SukhjeetkaurandSini S K, "Value based education: solution of today's problems”, University news 44 no: 49 December 4-10, 2006.

[11] UNESCO 1996 - "Learning: The Treasure Within": Report of UNESCO of the International Commission on Education for the $21^{\text {st }}$ century, Paris UNESCO. 